\title{
LANDFORMS OF MOUNTAINOUS KARST IN THE MIDDLE LATITUDES: REFLECTIONS, TRENDS AND RESEARCH PROBLEMS
}

\author{
RELIEFNE OBLIKE GORSKEGA KRASA SREDNJIH GEOGRAFSKIH \\ ŠIRIN: RAZMIŠLJANJA, TRENDI IN RAZISKOVALNI PROBLEMI
}

\author{
Ugo SAURO $^{1}$
}

\begin{abstract}
UDC 551.435.8

Ugo Sauro: landforms of mountainous karst in the middle latitudes: reflections, trends and research problems

Research into the landforms of karst highlands in the middle latitudes began in the "Classical Karst" in the $19^{\text {th }}$ century and has been marked by alternating periods of progress and stability since. In the beginning, the elementary morpho-types were recognized, in particular the circular closed depression defined as the "karst doline". Later the mid-latitude karst forms were compared with those of other climatic zones, especially tropical humid karst. In recent decades many papers have been published on the morphometry, the fillings, and models of the evolution of the surface karst landforms. It has been emphasized that in the mid-latitude karsts the morphogenesis is the result not only of karst solution but also of several other weathering processes such as cryoclastic (frost) action and other periglacial processes. Examination of the main scientific journals dealing with karst and other geomorphology shows that present day research in karst areas is mostly concerned with very specific subjects, such as speleogenesis, hydrogeology, sedimentology, geochemistry, mineralogy, cave biology, unusual landforms: only a minority of papers focus on karst surface landforms, and among these only a few attempt organic and comprehensive studies of the entire assemblage of relief forms in a karst morpho-unit. In reality, it is evident that the surface landform complex in a karst morpho-unit has to be considered in its entirety and that only such an integrated approach to this complex entity may bring significant progress in understanding. The landforms may be considered from different point of views, but always as a part of a holistic approach, in particular: a) in the geodynamic context of the evolution of the particular mountain group, b) as part of a complex geo-ecosystem, c) in the framework of models based on modern geomorphological concepts. Such comprehensive studies carried out by multiand inter-disciplinary research teams applying the most modern techniques and methodologies will present stimulating challenges not only for progress in karstology but also in all the environmental sciences.
\end{abstract}

Key Words: trends in karst research, surface landforms, middle latitude karst, karst morpho-units.

\footnotetext{
${ }^{1}$ Department of Geography of the University of Padova

Received/Prejeto: 13.07.2012
}

Izvleček UDK 551.435.8 Ugo Sauro: Reliefne oblike gorskega krasa srednjih geografskih širin: Razmišljanja, trendi in raziskovalni problemi

Raziskave reliefnih oblik visokega krasa se začnejo v 19. stoletju na Klasičnem krasu. Vse od takrat so zanje značilna obdobja stagnacij in obdobja napredkov. Za prvo obdobje je značilno spoznavanje značilnih morfoloških tipov, kot so npr. zaprte depresije, za katere se je uveljavil angleški termin "karst doline". Kasneje so reliefne oblike srednjih širin primerjali z oblikami drugih klimatskih con, predvsem tropskega in subtropskega krasa. V zadnjih desetletjih so objavljene številna dela, ki temeljijo na morfometriji, raziskavah zapolnitev in modelih razvoja kraških reliefnih oblik. Ugotavljajo, da razvoj kraških reliefnih oblik v srednjih geografskih širinah ni zgolj posledica kemične erozije, pač pa tudi drugih procesov preperevanja, kot so npr. krioklastični in drugi periglacialni procesi. Pregled sodobne literature kaže, da večina raziskav krasa poteka na drugih področjih, kot so speleogeneza, hidrogeologija, sedimentologija, geokemija, mineralogija, nenavadne reliefne oblike. Le malo del se posveča kraškim reliefnim oblikam, med temi pa so redka dela, ki obravnavajo celoten nabor oblik v kraški morfološki enoti. Reliefne oblike lahko obravnavamo $\mathrm{z}$ različnih vidikov, kot na primer: a) v geodinamičnem kontekstu razvoja določenega gorovja, b) kot del kompleksnega ekološkega sistema, c) v okviru modelov, ki temeljijo na modernih geomorfoloških konceptih. A le celosten pogled na površinske reliefne oblike v neki morfološki enoti bo prinesel napredek v razumevanju. Celovite interdisciplinarne študije, ki temeljijo na modernih metodah, bodo prinesle nove izzive tako na področju krasoslovja, kot tudi širše v vedah o okolju.

Ključne besede: trendi $\mathrm{v}$ raziskovanju krasa, reliefne oblike, kras srednjih geografskih širin, kraške morfološke enote. 


\section{STUDY OF THE SURFACE FEATURES OF KARST MORPHO-UNITS}

The karst surface relief of a mountain block composed of soluble rocks such as evaporites or carbonates is the external face of a complex system with a long history. The simple study of such surface features alone is only a first approach to understanding the landforms and their natural history.

In the early development of karst studies the analysis of the surface landforms has been "superficial" in many respects. There were only approximate qualitative descriptions of the main types of forms, seeking to divide them into individual elementary karst "morpho-types" and their settings in characteristic karst landscapes.

Starting from such landscapes and from models already developed for other morphogenetic environments such as the Davisian theory of a 'cycle of erosion' in 'normal' (fluvial) environments in large orogenic chains, the first evolutionary models of a 'karst cycle of erosion' have been applied arbitrarily to karstic relief (Ford \& Williams 2007), even if the real karst mountains did not fit such models. The ease of criticism of such models discouraged many researchers from formulating specific evolutionary theories based on the real characteristics of the karst massifs they were studying.

The second important phase of development in the research was stimulated by comparisons of the populations of karst forms in different regions of the Earth's surface in the context of the concepts of 'climatic geomorphology'. Such concepts have been applied to karst phenomena since the 1950s, especially by the German School, and have led to stimulating progress in the study of karst relief (Lehmann 1954).

In particular, a simplified model of the typical relief of the mid-latitudes karst, the so-called "classical karst" that refers to the Carso of Trieste and the Slovene Karst plateau, was compared with typical karst areas of other climatic zones, especially with those of the humid tropical zones. The most evident difference is that while the tropical karst is dominated by positive forms, such as towers, cones, domed hills, the mid-latitude karst is mostly characterized by negative relief forms such as dolines, uvalas, poljes, etc. At approximately the same time the first quantitative analyses and models of the rates of the karst denudation processes were undertaken (Corbel 1957).

In the second half of the past century and the first decade of the present one, hundreds of studies have been carried out on the geomorphology of karst mountain regions (White 1988; Salomon 2000; Ford \& Williams 2007). Such studies have increased the awareness that each area of karst relief is a very complex entity, different from any other in many features, and that it is nearly impossible to obtain a comprehensive understanding of such entities, even with very specific research programs. Even an interdisciplinary research program on a particular karst geo-ecosystem carried on for years by a large team of researchers, will only result in a preliminary overview, preliminary models and provisional conclusions, a kind of state of the art report on that specific study that is still open to new improvements.

If we examine the indexes of the main scientific magazines dealing with karst, such as the 'International Journal of Speleology', 'Acta Carsologica, 'Karstologia', 'Cave and Karst Science,' 'Die Höhle, 'Journal of Cave and Karst Studies', 'Speleogenesis and Evolution of Karst Aquifers', it is readily seen that only a minority of papers is related to karst surface landforms (roughly 20\%), and of these only a few attempt organic and comprehensive studies of the entire assemblage of the relief forms in a karst morpho-unit. In international geomorphological journals such as 'Geomorphology' and 'Zeitschrift für Geomophologie', the papers on karst topics are mostly related to the surface geomorphology but here also there are only a few holistic studies of all of the landforms comprising the karst morpho-unit.

As a result it is evident that most karst researchers are accustomed to making specific studies of the speleology, or speleogenesis, hydrogeology, sedimentology, geochemistry, mineralogy, cave biology, unusual landforms etc., instead of carrying out studies of the 'regional geomorphology' of their karst areas. A possible explanation of this is the fact that most karst researchers have not been exposed to a serious programme of geomorphological studies in their training, and also that study of a geomorphological assemblage of forms in a selected morphotectonic unit is often avoided because it is much more problematic than the study of a single form.

In its first part this paper offers reflections on the specificity of surface landforms of the mid- latitude karsts from a geomorphological prospective, and in the second part it highlights the problems and the possible evolution in future karst research on the topic, stressing comprehension of the holistic karst system in its spatial and temporal dimensions and complexity. 


\section{SOME DISTINCTIVE CHARACTERISTICS OF THE MIDDLE LATITUDES KARST}

As previously noted, the landforms of the mid-latitude karst are different from those of the humid tropical areas: in particular the positive forms are much less expressed and the negative forms such as dolines are normally smaller in the former than in the latter. This difference is easy to explain, because in tropical karst the solution process is the dominant 'denudational' agent, while in the mid-latitudes, it is more common to find landforms resulting from the combined action of two or more morphogenetic processes. In particular, periglacial and glacial processes have been more effective during the cold periods of the Pleistocene and were responsible for "dismantling' the positive forms and depositing their debris inside the depressions (Bočić et al. 2012).

In periglacial environments in mid-latitude mountains, cryoclastic weathering acts less as a morphogenetic agent and more as an antagonist of karst morphogenesis: in practice, deepening of dolines is slowed down both by the clastic infilling action and by consumption of dissolution potential of the surface and soil waters in that rocky debris accumulated in the bottoms of the depressions; at the same time the evolution of the positive relief forms is inhibited or slowed down.

At this point it is fundamental to stress the influence of the lithology on the evolution of the landforms. Some limestones are very resistant to cryoclastic weathering (i.e. gelifraction), others are less resistant or very susceptible to it. Some beds split into large fragments, others into medium or small sizes. These vulnerabilities are defined as macro- meso- and micro-gelivity.

As a result, in the mid-latitudes karst, the creation and enlargement of dolines occurs most readily in rocks less sensitive to gelifraction; where the rocks are massively bedded and thus very resistant to this process large and deep depressions may be found and sometimes also conical or domelike hills between the depressions. This evidence shows that in such rocks karst morphogenesis is relatively less disturbed, even in high mountain environments where frost action against bedrocks is very aggressive (Sauro 2007). Good examples of the evolution of karst landscapes in such aggressive environments are found in the Venetian Prealp massifs such as Monte Baldo, Faverghera Plateau (Col Visentin), CansiglioCandaglia (all in Italy), and in the Velebit Mountains in the Croatian Dinaric karst.

From the morphometric analysis of dolines in karst morpho-units such as the Classical Karst of Trieste, it is possible to recognize different populations of depressions that result from multiple episodes of development (Bondesan et al. 1992; Sauro 2012). It is evident that there has been a succession of "karst morphogenetic phases" that alternated with "anti-karst morphogenetic phases" when there was a partial destruction of the karst forms. After each "anti-karst phase", some of the dolines are able to recover their functionality and to continue to evolve as closed depressions, others are aborted and remain as crypto-forms or are completely destroyed.

Some karst morpho-units such as the Montello Conglomerate Karst allow us to compare the forms that evolved on surfaces of different ages, showing that the "karst morphogenetic phases" clearly prevailed over the "anti-karst morphogenetic phases" (Fig. 1).

One complicating factor is caused by the transport and deposition of local or allochthonous fine-grained sediments (silty, paleosol and loess-like sediments) within the closed depressions, which are acting as traps. In particular, in periglacial environments paleosols are easily eroded by overland flow, solifluction, creep, congelifluction, etc., especially on steep slopes, and accumulate within the depressions where they may reduce the permeability of the doline system, transforming it from an 'open' to a 'semi-open' or a 'semi-closed' one. Such fillings may also reduce the quantities of water flowing at the soil-rock interface and consequently slow down chemical erosion of the underlying rock and the rate of deepening of the depressions (Nicod 1975; Zambo 1985, 1991; Ballut et al. 2012).

From this description it clearly emerges that it is not sufficient to know the topographic expression of a landform (i.e. the shape of the lithosphere-atmosphere interface), but it is essential as well to investigate the subsoil structure that expressed by the interfaces between the host soluble rocks and the cover and filling deposits (Williams 1985; Sustersic 1994; Gams 2000; Sauro 1995, 2012) plus the interfaces between the different types of fillings. Karst depressions and caves with few or no fillings are much easier to investigate and describe than landforms with very thick fillings. It is also important to recognize that a doline is the surface expression of the epikarst, a network of solutional voids developed as secondary porosity in the uppermost zone of the soluble rock. Such voids may be partly empty or partly or largely filled by sediments: in time, following denudational lowering of the topographic surface, some of these voids become open to the surface, influencing the shaping of the landform.

In the evolution of the landforms, one complicating agent is that of active tectonics modifying the morpho-structures. In practice, morphotectonic events may produce new fractures in the rock mass that create fault scarps and/or modify the slope of the surface, tilting, up- 


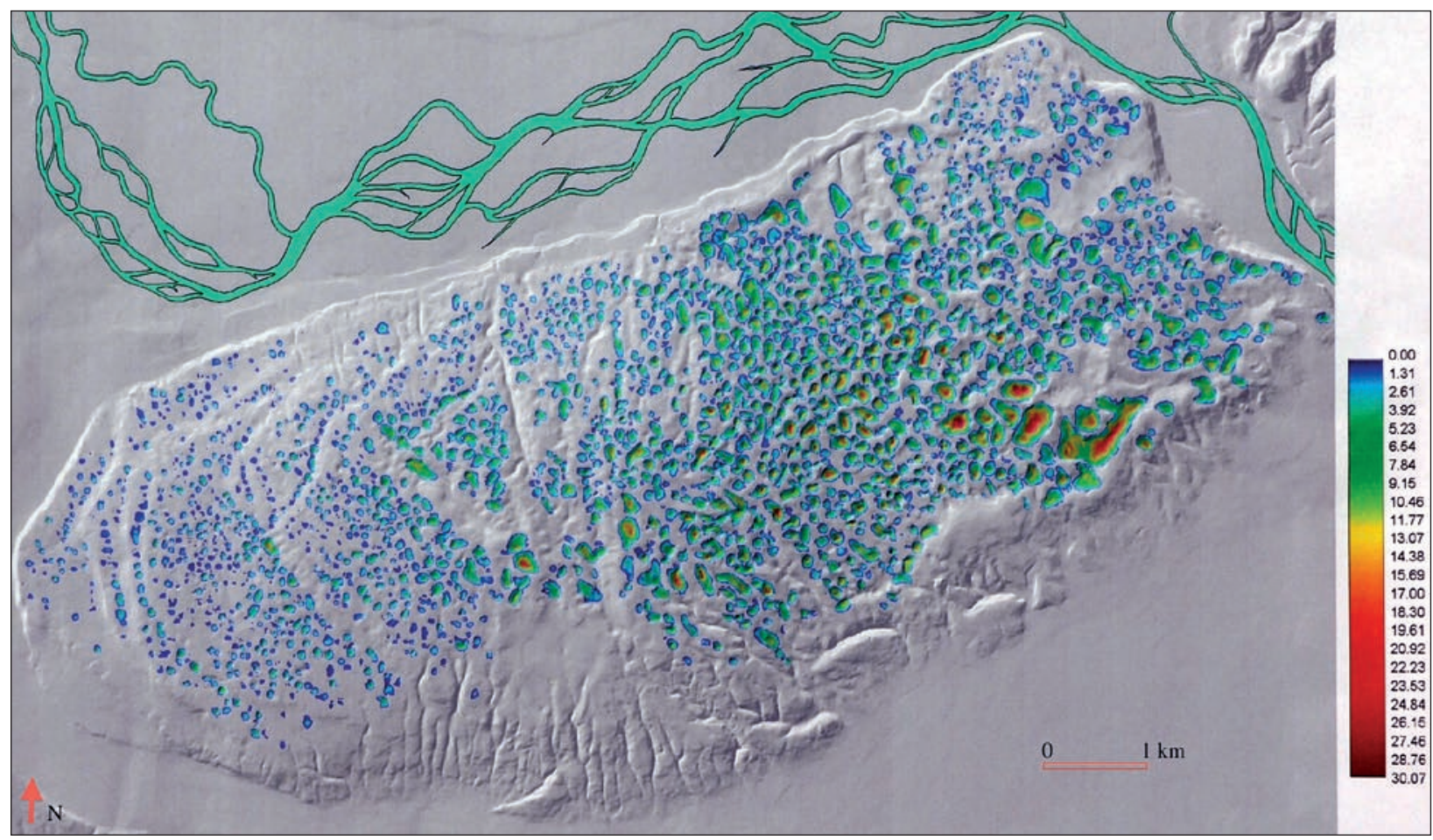

Fig. 1: DEM of Montello Hill (Venetian Prealps, Italy) with populations of dolines of different ages. The youngest are those on the rockcut terraces situated on the west side; the oldest are in the central and east side; the chromatic scale indicates the depths of the closed depressions in meters (DEM by Francesco Ferrarese).

lifting or lowering it. Examples of the influences of the tectonics in the evolution of forms are recognizable in many poljes (Gams 1994) and uvalas (Ćalić 2011). Ex- amples are also found in Naole in Monte Baldo in the Venetian Prealps and along the western foot of the Velebit chain (Faivre et al. 1999, 2002).

\section{INTERFERENCE BETWEEN KARST PROCESSES AND OTHER MORPHOGENETIC PROCESSES}

In the mid-latitude karst regions it is more common than in the humid tropics to detect landforms that result from the combined action of two or more morphogenetic processes. In reality, however, in the karst of the humid tropics many forms and landscapes also result from the synergic action of fluvial and karst processes, e.g.: 1) the "open polje" type plains, with the tower and cone karst; 2) cockpit karst where a star like system of stream valleys converges in the closed depressions, 3) gorges resulting from both from the downcutting of allogenic rivers and by the collapse of large underground galleries. However, in the mid-latitude karst there is a larger variety of forms resulting from the synergic and/or alternate, and/or episodic morphogenetic action of diverse processes (Tab. 1).
It is difficult to define exactly the large variety of types of forms that may result from the combined action of two or more processes, also because several variables may affect the results. Here, only a brief discussion about the glacio-karstic (Fig. 2) and the karsti-glacial forms will be presented. The distinction between these two categories is based on the first process to imprint the forms: if some glacial forms are modified by karst processes it is correct to speak of glacio-karstic forms; on the contrary, if some karst forms are modified by the glacial processes the resulting forms have to be considered as "karsti-glacial". In a review of alpine karst in the southern Rocky Mountains of Canada (1979), Derek Ford suggests to compose the names with the opposite 


\begin{tabular}{l|l|l}
\hline Processes & Class of forms & Some specific forms \\
\hline $\begin{array}{l}\text { karst and fluvial } \\
\text { (fluvial is intended in sensu lato) }\end{array}$ & fluviokarstic & $\begin{array}{l}\text { - fluvial canyons } \\
\text { - dry valleys } \\
\text { - blind valleys } \\
\text { - pocket valleys } \\
\text { - uvalas } \\
\text { - poljes }\end{array}$ \\
\hline karst and glacial & $\begin{array}{l}\text { - glaciokarstic depressions } \\
\text { - limestone pavements }\end{array}$ \\
\hline karst and periglacial & karsti-glacial & $\begin{array}{l}\text { - nivo-karst niches } \\
\text { - dry valleys with periglacial } \\
\text { deposits (dells) } \\
\text { - rock cities (ruiniforms) }\end{array}$ \\
\hline & karstic and periglacial \\
& &
\end{tabular}

Table 1 - Some processes and related forms found in the midlatitude karst

order, i.e.: "karsti-glacial" if a form of glacial origin is adapted by karst processes; and "glaciokarst", if a karst form is modified by glacier action. The use of the terms previously suggested in this paper may be justified by the application of the "principle of superposition" of the geologic stratigraphy, stating that the oldest objects must be placed first, and, if so, a landscape is "glacio-karstic" if the first process to imprint it was that of the glaciers.

The problem is that many forms have been subject to alternations through several phases and it is often difficult to trace back to the first generation. For example, if we find a glacial cirque with a glaciokarstic depression on the bottom evidently the predominant, and probably the oldest, form is the cirque and so the complex form has to be considered "glacio-karstic". In contrast, where we find a family of closed depressions on a high plateau that are clearly affected by glacial abrasion and elongated in the ice flow direction, it is clear that the original forms were karst dolines and so the final landscape may be considered as "karstic-glacial".

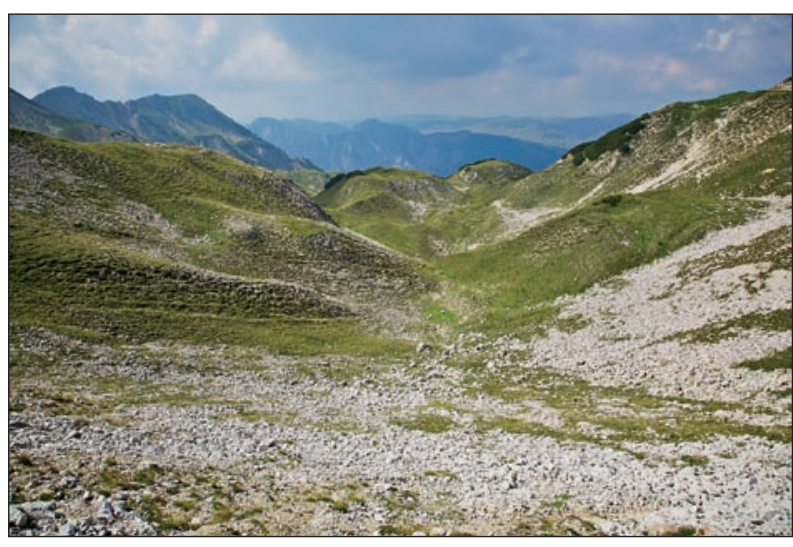

Fig. 2: Irregular relief with large closed depressions in the Upper Dolomite of the southern Dolomitic Group of Carega (Venetian Prealps, Italy). At an elevation of 1800-2000 $\mathrm{m}$ asl, the scene is the result of karst, glacial and periglacial processes.

\section{THE PROBLEM OF DESTRUCTION AND/OR INHERITANCE OF KARST AND MIXED ORIGIN FORMS}

The evolution of the relief of karst morpho-units may be more or less complex depending on: (1) the initial conditions, (2) the climatic conditions and changes, (3) the character and interrelations between active tectonics and erosional processes, (4) the litho-structural composition of the rock massif and the changes to it produced by the denudation.

For example if we consider a model which (1) begins with a nearly flat surface (planation surface) that is uplifted and only slightly deformed, (2) is subject to progressive uplifting that is not much faster than the rate of denudation and consequently of the erosional lowering of the surface, and (3) is a relatively pure, homogeneous and very massive limestone unit, then dolines will develop and, in time, will tend to colonise all of the surface, competing with each other and reaching a metastable equilibrium with the "geodynamic" environment (here the term "geodynamic" is 'sensu lato, considering both the dynamics of the lithosphere and that of the atmosphere): clearly, changes of the tectonic style and/or of the climate may alter the forms to a varying degree but, once developed, a population of large dolines tends to persist, and to 'migrate' downwards through the stratigraphic sequence even where tectonic uplift is occurring.

As a consequence, if the limestone unit is very thick (i.e. more than one $\mathrm{km}$ ) and the uplift started sev- 
eral million years ago it is likely that a doline we can observe in the present landscape has a very long history: it could be derived from a depression that began hundreds of meter higher in the stratigraphic series and perhaps at a lower or similar altitude (according to the absolute elevation asl), several million years ago. Histories like this may be recognized in such typical highland karst as the Candaglia Plateau in the Cansiglio-Cavallo Group (Venetian Prealps, Italy) where there are large dolines (hundreds of meters in diameter) in thick rudist reef limestone of Cretaceous age, which are in some respects similar to that of the Classical Karst and of the western Dinarides. The geomorphological history

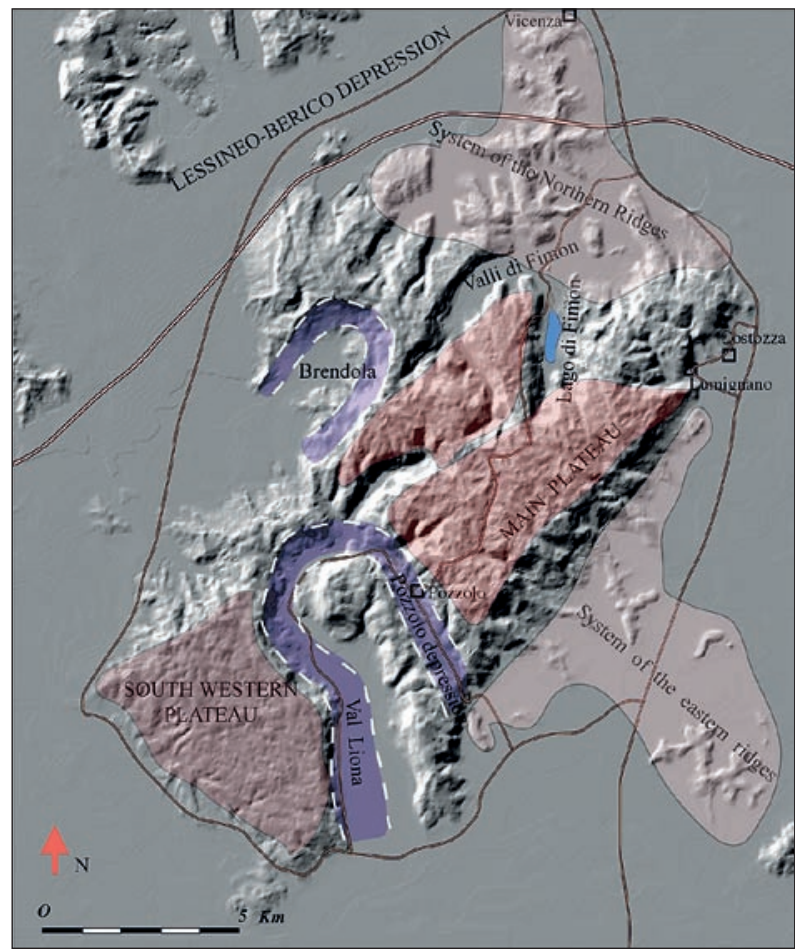

Fig. 3: The principal geomorphological units of the Berici Hills (Venetian Prealps, Italy) where it is easy to recognize a morphostratigraphy of upland surfaces and relict segments of antecedent valleys of different ages and origin. Karst plays an important role in the evolution of these forms.

of Montello Hill (Venetian Prealps) that is composed of a thick conglomerate formation is also similar. The geomorphological history is much more complicated if the morpho-unit is composed of several different rock types, even if all consist mainly of soluble carbonates. Nice examples of this complexity are recognizable in the morpho-units forming the Venetian Prealps of NE Italy, especially the mountain groups between Lake Garda and the Piave River. Here the possible evolution of some real landscapes will be described.
The Berici Plateau in the Prealps was created by the uplift of a fluvial planation surface. Within the plateau entrenched segments of large fluvial antecedent relict valleys, now hanging above the surrounding alluvial plain, are easily recognizable (Fig. 3; Sauro 2002). On the erosional surface, which is mostly cut into Eocene and Oligocene limestones, remnants of a cover of up to some tens of meters of fluvial sediments are still present. This cover first favored the development of a local hydrographic network. Later, cover dolines, uvalas and blind valleys began to develop on the plateau (Fig. 4) and springheads at its margins. Next, drainage via the closed depressions prevailed over the open valleys, which became dry. Where the Eocene limestone has been eroded away, however, the underlying Scaglia Rossa limestone (Upper Cretaceous) did not inherit the dolines. Instead it behaves as a resistant layer and tends to develop structural mesa-like surfaces that are locally cut by fluvial gorges.

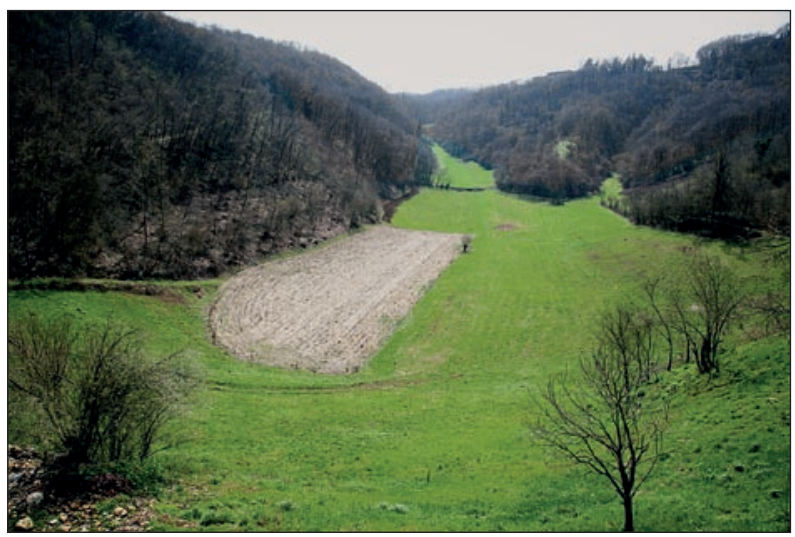

Fig. 4: A blind valley in the Berici Plateau, Venetian Prealps, developed first on alluvial deposits covering an erosional surface in limestone and later affected by karst processes.

Where the Scaglia Rossa has also been eroded away, as it is in several other mountains groups of the Italian Prealps such as Lessini, Asiago Plateau, Monte Grappa, the Maiolica (also called "Biancone"), a marly limestone of Lower and Middle Cretaceous age that is thinly bedded and strongly fractured (like the Chalk of the Paris Basin) outcrops. Here we find networks of dry valleys separated by systems of rounded ridges with convex slopes (Sauro 1973).

Following erosion of the Maiolica, the networks of dry valleys were often superimposed on the underlying Jurassic limestones, which favour the formation of dolines. But, once developed, a dry valley in the Jurassic limestones tends to be perpetuated because its bottom is affected by accelerated solution, in contrast to conditions on the slopes. Eventually some dolines develop inside the floor of the valley (Fig. 5). 
This sequence, easy to reconstruct when compared to other areas of the Venetian Prealps, shows how, among other controlling factors, the lithological changes may affect the morphogenesis and how different landscapes may evolve, even if they are next to each other and even if the active tectonics and the climate are the same.

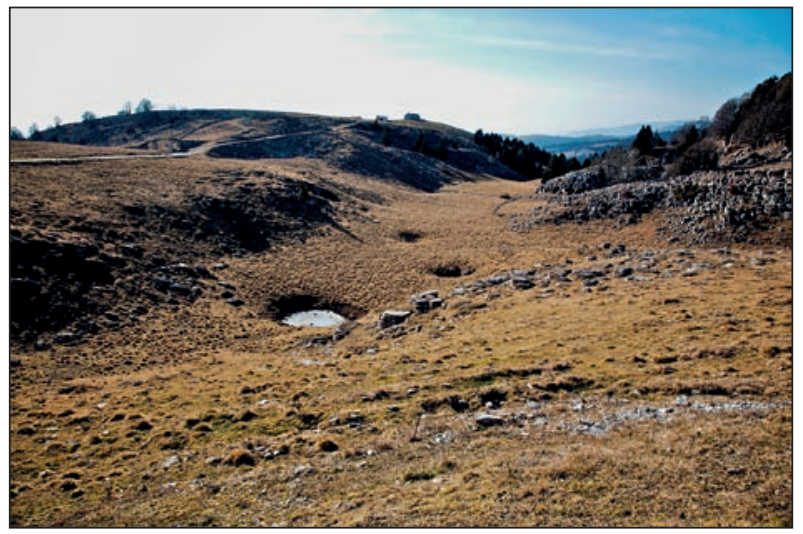

Fig. 5: A dry valley in the Jurassic limestones in the Lessini Mountains, Venetian Prealps. It is the result of a process of superimposition starting from a network of dry valleys developed on the Maiolica (Lower Cretaceous) limestone formation that is now eroded in the area. Some dolines have developed in the flat bottom of the valley.

As a result, a landscape characterized by dolines may be destroyed following the complete removal of its "parent rock" and the exposure of the underlying stratigraphic unit, and be transformed in a fluviokarst landscape. Similarly, with removal of its "parent" rock, a fluviokarst landscape may be superimposed on a pure limestone that is otherwise, very suited for the development of dolines. Thus the stability or instability of a system depends on the interrelations between several factors and in particular between the surface landforms and the constituent materials: if one of these two changes, probably the others will change also or play a different role.

In a karst area the landforms may be more or less active and/or inactive. So, some dolines may enlarge and deepen faster than others, as also will some dry valleys.

Some landforms, termed 'relict forms', may be the result of past situations and/or conditions that are no longer present or active. Such forms may survive for long time in a karst environment, which is often very conservative compared to a fluvial landscape (i.e. a planation surface or an antecedent valley abandoned by the river). A dry valley network developed in Chalk and superimposed on a underlying pure and massive limestone may be considered to be an inherited relict form.

It is important to remember that the term 'fossil form' must be applied only to landforms which are inactive because they are completely filled or buried by a thick cover of sediments protecting them. Eventually such forms may be exhumed and reactivated following the removal of the fillings and/or overlying rocks.

A peculiarity of the karst relief is the presence of surface forms determined or influenced by the intersection of the topographic surface with old underground forms, sometimes fossil ones. Examples are collapse dolines and 'unroofed caves' (Mihevc 2001, 2007; Mihevc et al. 1998), also defined as "intersection dolines" (Sauro 2012). Some of these forms evolve into dolines or as dry valleys and, despite their origin, may become indistinguishable from the surrounding solution dolines.

Thanks to this capacity to preserve old forms, in karst terrains it is often possible to recognize a morphostratigraphy that results from the very complicated history of the morpho-unit. A good example of such a morphostratigraphical setting is seen in the Berici Plateau (Venetian Prealps; Sauro 2002).

\section{UNDERSTANDING OF THE SIGNIFICANCE OF SURFACE LANDFORMS IN THE CONTEXT OF THE LOCAL KARST GEO-ECOSYSTEM}

A karst morpho-unit such as a plateau or a mountain massif, is very suitable for study as a geo-ecosystem (Castiglioni \& Sauro, 2002), i.e. as a functional system characterized by a distinctive three-dimensional structure, and by exchanges of matter and energy among both the sub-components of the system itself and the surrounding systems.

Therefore it is important (1) to analyze and define the structure of the system; (2) to consider the functioning of the whole system with regard to its fluxes of matter (clasts, solutes, and gases) and energy (solar radiation, geodynamic and climatic) in the specific environment surrounding it; (3) to understand the interrelationships between sub-components of the system, i.e. the surface landforms and the underground networks of cavities; (4) to consider different types of impacts resulting from environmental changes and human activities.

In order to do this it is important on one hand to explore and define the boundaries of the system, on the 
other to undertake different types of analyses using all possible methodologies.

Karst systems offer extraordinary opportunities to study and understand the functioning of natural systems. Other systems such as the fluvial and glacial, do not offer comparable opportunities to determine the true depth of the system itself or offer the possibility of direct access to its deepest parts (e.g. within caves).

A karst geo-ecosystem is very well suited for modeling its physical components and dynamics. The conceptual itinerary of such an effort is schematized, at least partly, in a sketch published by Castiglioni and Sauro (2002) and Sauro (2009).

Of course, the transition from a conceptual scheme to a real physical model is not easy. There are so many variables and the physical behavior of the different components is difficult to establish because of the inhomogeneities inside the system itself. The realization and verification of a good physical model of a karst morpho-unit is certainly a big challenge as it implies the understanding of a complex natural system.

\section{PROBLEMS OF MODELLING}

The aim of this paper is not to deepen discussion of the previous topics, even if it can be very stimulating to consider the role played by different assemblages of surface landforms in the relative geo-ecosystems and the correlations between the evolution of the surface and that of underground parts of a karst system.

Here it is probably useful to consider the surface karst landforms, seeking to apply to them some of the conceptual bases of geomorphology. In recent decades some geomorphologists have sought to investigate how landforms and landscapes respond to variable boundary conditions and to disturbances, and how geomorphic systems co-evolve with climate, ecosystems, soils, and other environmental components.

The basis of such concepts and models are enunciated in Brunsden and Thornes (1979), Brunsden (1990, 2001) and have been repeated by Thomas and Allison, (1993) and Phillips (2009).

In particular Brunsden (1990) illustrated and discussed the "ten commandments of geomorphology". In the tenth commandments he summarizes some concepts relating in particular to the evolution and metastability of landforms. He writes that within any tectono-climatic domain it is possible to recognize the "tendency toward an all pervading unity and a repetitive but characteristic geometrical order and regularity ..... The reasons for this apparently paradoxical situation are built into the propositions of geomorphology: a) Preferential selection of stable forms, b) Exponential decrease rate of change, c) Increasing effectiveness of barriers to change, d) Constancy of process, e) Persistence, $f$ ) Convergence, $g$ ) Over-relaxed systems, $h$ ) Self propagation, i) Preferential fabric-relief pattern, j) Process smoothing and extreme event accumulation."

The basic concepts were re-examined and very well defined by Phillips (2009):
"Landscape sensitivity: the probability that a given change in boundary conditions or forcing of a geomorphic system will 'produce a sensible, recognizable, and persistent response'.

Resilience: the ability of a system to recover from disturbance toward the pre-disturbance state and the degrees of freedom available to absorb or adjust to disturbance.

Geomorphic relaxation time: the time required to complete a response to a landform-changing shift or event.

Reaction time: is the time required for the system to begin responding, and relaxation time is that needed to complete the response. Reaction time is often directly related to the frequency and timing of trigger events.

Relaxation time ( $R i$ - is a measure of the landscape sensitivity): let Ri be the relaxation time in response to event ' $i$ '. The ratio of $R i$ to the frequency of the event (Fi) gives the transient form ratio (TFR) of Brunsden and Thornes (1979).

Resistance: is the ability of a system to avoid or minimize responses to externally imposed changes. Dynamically stable systems are likely to be less sensitive and more resilient than unstable ones.

Recursion: Responses to change often feed back upon themselves. These recursive feedbacks may either be positive, reinforcing and thus perpetuating or even accelerating the change, or negative, slowing or even negating the change."

When we apply such models and concepts to real mid- latitude karst landscapes there are many different examples; for instance, in the Montello Karst each of the seven rock cut terraces is the expression of a geocatastrophe - in the sense of a radical system change: but here it is probably more correct to speak of 'geomorphocatastrophe, i.e.:

- for each of these surfaces the tectonic event (probably in cooperation with climatic cycles influencing the 
fluvial dynamics) caused a transition from a fluvial formative condition to a karst formative condition;

- here the geomorphic relaxation time is longer than one, or perhaps even two morphotectonic episodes or ('geomorphocatastrophes'); on the youngest terrace above the active fluvial planation surface, the karst dolines are not yet expressed as clear surface depressions;

- after the development of well-expressed relief characterized by karst dolines, the landscape sensitivity to climatic changes such as the cold phases of the Pleistocene has been relatively low, the resistance of the system has been high and the resilience good.

But if we observe the older planation surface of the eastern plateau of Montello Hill (Fig. 1) where in the most recent cycles the rate of uplift seems to have slowed down and probably in the last phases was less than rates of lowering by denudation, the karst relief is now changing from a population of single dolines to an assemblage of more complex and larger depressions (a kind of 'composite dolines' and uvala-like basins). Here, the topographic surface is approaching the water table, which has begun to affect the morphogenesis.

In the case of the mountain groups mentioned in the Venetian Prealps, where there are several different carbonate lithologic units in the structures, the erosional transition from a given rock unit to the lower one often corresponds to a geomorphocatastrophe. Here the landform-changing shift or event is caused by the 'abrupt' transition from one rock type to another, which changes the boundary conditions or forces the geomorphic system, producing a sensible, recognizable, and persistent response'.

In contrast, if we apply the same concepts to an alpine karst like Monte Baldo or the southern sector of the Velebit range, we see that the landscape sensitivity to climatic changes such as the cold phases of the Pleistocene has been relatively high, the resistance of the system has been low and the resilience poor. In these two karst areas the mesozoic bioclastic limestone units are sensitive to cryoclastic weathering and periglacial processes have effectively dismantled the karst relief, most dolines have been destroyed and/or infilled. Probably, tectonic deformation and, in particular, the tilting of the plateau surfaces has also favored the destruction of the dolines. In comparison with these examples, however, the dolines in the central Velebit range that are developed in a very massive limestone breccia have continued to enlarge and deepen because this rock type is very resistant to cryoclastic weathering: it is a paleo-breccia that behaves like a homogeneous rock, similar to a granite in some respects such as large scale exfoliation by relaxation. The local glaciation has not affected the forms very much, probably because the plateau glaciers were rooted in the dolines and very thin outside of them. Here, where the Quaternary climatic and environmental changes have been large, the changes of the landforms have been modest and the landscape sensitivity to climatic changes has been low, the resistance of the system has been high and the resilience good.

In some areas it is possible to recognize assemblages of landforms resulting from old formative events which are, in some respects, relict forms, now consisting of unusual systems which are resistant to changes of their morphogenetic styles.

The karst relief of the coastal belt of the Velebit range is a curious and interesting example, consisting of a population of large dolines that are more similar to cockpits than to the mid-latitude 'normal' dolines. Here the positive forms, represented by dome-like hills or conical hills, are often better expressed than the closed depressions (Fig. 6). Some of these hills are seen to extend up the steep slopes of the mountain front, where closed depressions are no longer present.

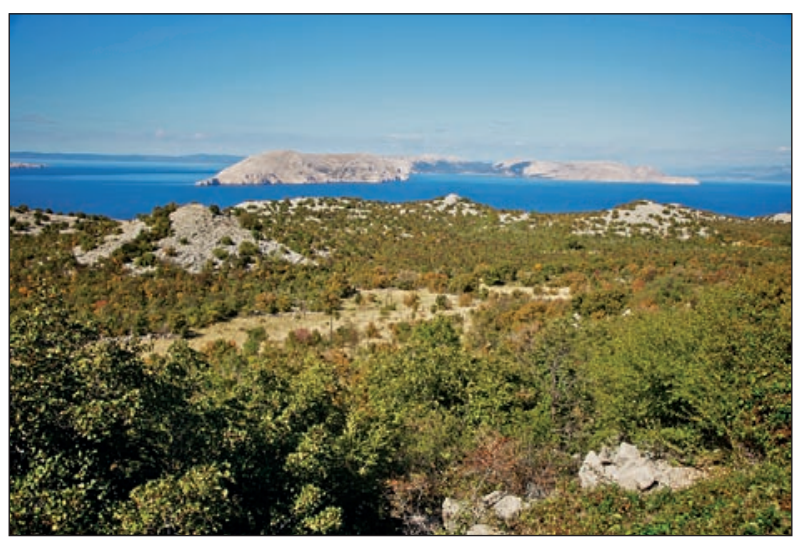

Fig. 6: A large cockpit-type doline in the coastal belt of Dalmatia at the western foot of the Velebit Range, Croatia. The depression is shallow and characterized by a polygonal perimeter with domelike hills.

Also in the upper Murge Plateau (Central Puglia, Southern Italy) there is a population of large karst depressions interpreted as a low relief cockpit karst (Sauro 1991), that developed in the late Neogene, starting from a staircase of uplifted marine planation surfaces. Due to the geographical position and the low altitude, this relief has survived the climatic changes of the Pleistocene and is still active, even if the main karst formative event probably ended some million years ago. So here the resistance of the system is good and the resilience high.

Part of the Neretva Plateau (Bosnia), as we see it today, consists of a subhorizontal erosional surface interrupted both by positive and negative forms, by hills and ridges and by the entrenched gorges of the Neretva 
River and some of its tributaries. The plateau may be interpreted as an old open polje similar to those of the humid tropics. The hills are residual relief features more or less modified by active tectonics; the gorges are the result of the downcutting of the hydrographic network following the tectonic uplift and consequent relative lowering of the base level. So the plateau is a relict and now inactive "open polje" on which only a few dolines have developed. Here the karst formative event - from the point of view of the development of a population of dolines on the plateau - has certainly begun but the geomorphic relaxation time is long, perhaps because of shielding by fine-grained fluvial sediments on which clayey soils have developed. In southern Montenegro and northern Albania an "open-semi-polje" is active now (Fig. 7).

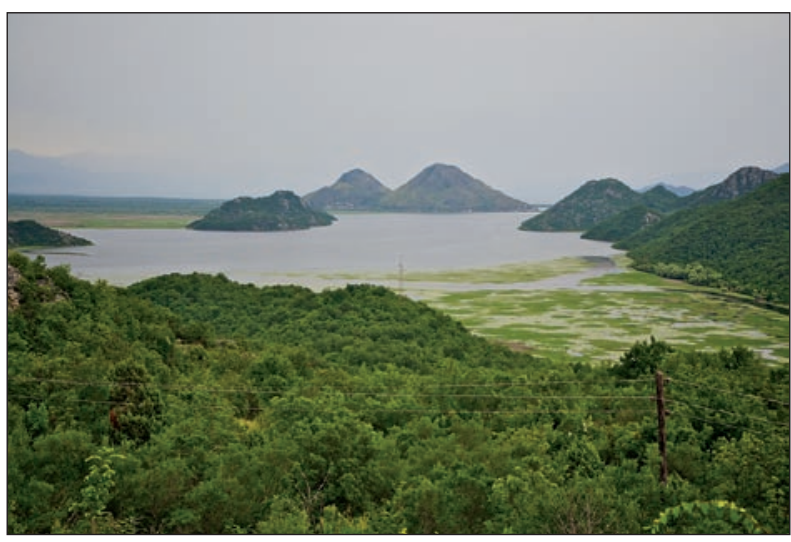

Fig. 7: An open semi-polje that is still active, seen here at Skodarsko Lake between southern Montenegro and northern Albania.

\section{NEW CHALLENGES IN KARST RESEARCH}

Due to the intrinsic complexity of natural karst systems and their environments, all the different approaches to karst studies present extraordinary challenges for the karst researchers, even where improved by the application of new methodologies. Certainly, multi- and interdisciplinary research projects that are done well may make leading contributions at the international level to the science of the environments of our blue planet, and at the same time stimulate research on other different natural environments.

Here only a few points about the extraordinary possibilities that have been recently opened by new methodologies are indicated:

- the potential application of LiDAR to the study of the surface landforms,

- quantitative analysis of the trace metals, including many isotopes, by ICP mass spectrometry,

- the monitoring of environmental parameters with probes and data loggers.

LiDAR (Light Detection and Ranging, also called "laser radar") is able to furnish remarkable large scale images of the terrestrial topography, reducing the filter effect of the vegetation cover. In such images it is possible to get a remotely-sensed perception of landforms that is much better than that in large scale topographical maps derived by aero-photogrammetry, and to see details difficult to recognize in field surveys also (Fig. 8).

ICP mass spectrometry allows detection of the trace elements (in particular, metals), in a system and in its different components, often at infinitesimal scale (parts for trillions), which increases understanding of the significance of their presence and varying concentrations.
Some metals can yield fundamental information about the age of selected deposits (as with the isotopes of Uranium and Thorium): others may be used as tracer elements or indicators of different kinds of human impact.

In recent decades automated probes and data loggers recording important environmental parameters such as temperature, conductivity, humidity, etc, have become commercially available and are always more sensitive and precise (and also cheaper) than in the past. Such data loggers, if installed in selected places in a karst morpho-unit and/or geo-ecosystem, allow collection of time series of thousand of measurements that are very easily correlated with other parameters and very useful for understanding the dynamics of the system itself. Such data are fundamental for the definition of a physical model of a karst system. Once sketched out, a model may be compared with the real system and progressively improved through further monitoring and analyses.

There are many other important fields of research but karst researchers have not to forget that direct contact with the real karst environment is fundamental for improving their knowledge. Therefore the role of speleologists is very important, but also geomorphological study of karst surfaces and sampling and analysis of the karst sediments, both clastic and chemical. It is important not to overlook opportunities such as those represented by the opening of quarries and building of roads. The Karst Institute of the Slovene Academy of Sciences is a very good example of a leading organization promoting karst research, not only in Slovenia but all over the world. By visiting the Institute web site it is seen that the scientific productivity is very good and an expression of 


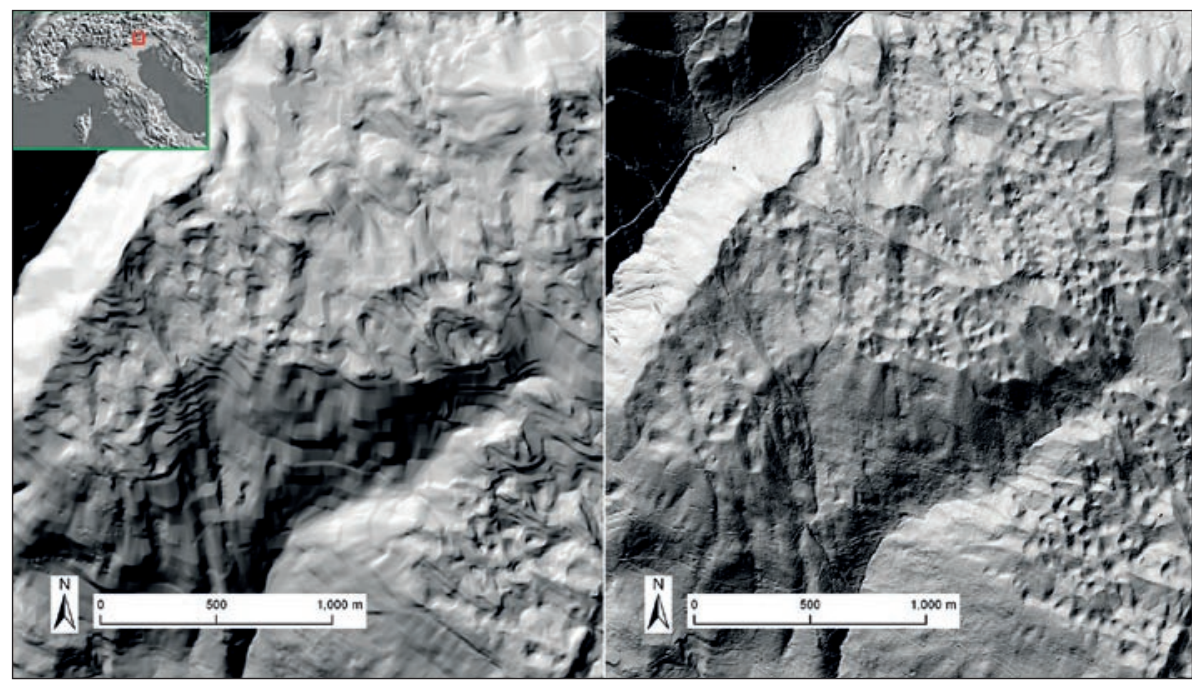

Fig. 8: A sector of the Cansiglio-Cavallo Group, Venetian Prealps of Italy, represented both in a DEM based on $5 m$ interval contours and survey points from the CTR 1:5000 Veneto Region digital maps (left), and in a TIN of LiDAR last pulse data at 1.07 points $/ \mathrm{m}^{2}$ (right). The relief representation in the two models is very different: the details of the karst forms are impressively better in the TIN. Elaboration of data by Francesco Ferrarese. By courtesy of Provincia di Treviso, and of the research group of A. Bondesan, F. Ferrarese, V. Posenato which is now carrying out geomorphological studies of the area.

an integral approach to and contact with the karst environment.
In the recent decades, karstology has certainly gained in appreciation among the natural sciences, its potentialities proven by the progress illustrated in many different papers, published in specialist journals, books and encyclopedias. However, it remains possible to substantially improve research work promoting inter- and multidisciplinary studies of karst geo-ecosystems and models of their structure and spatial and temporal framework.

The Author wishes to thank Dr. A. Mihevc for the invitation to present a lecture at the Karstological School 2012 in Postojna from which this manuscript is derived, Prof. Derek Ford for the very precise editing of the English text, and two Anonymous Referees for helpful comments and useful suggestions.

\section{REFERENCES}

Ballut, C. \& S. Faivre, 2012: New data on the dolines of Velebit Mountain: An evaluation of their sedimentary archive potential in the reconstruction of landscape evolution.- Acta Carsologica. 41, 1; 59-74.

Bočić, N., Faivre, S., Kovačić, M. \& N. Horvatinčić, 2012: Cave development under the influence of Pleistocene glaciation in the Dinarides - an example from Štirovača Ice Cave (Velebit Mt., Croatia).- Zeitschrift für Geomorphologie. 56, 4; 409-433.

Bondesan, A., Meneghel, M., \& U. Sauro, 1992: Morphometric analysis of dolines.- Int. Journal of Speleology, 21(1-4), 1-55.

Brunsden, D. \& J.B. Thornes, 1979: Landscape sensitivity and change. Transactions of the Institute of British Geographers NS 4, 463-84.

Brunsden, D., 1990: Tablets of stone: towards the ten commandments of geomorphology.- Zeitschrift fur Geomorphologie suppl. 79, 1-37.
Brunsden, D., 2001: A critical assessment of the sensitivity concept in geomorphology.- Catena 42, 99-123.

Ćalić, J., 2011: Karstic uvala revisited: Toward a redefinition of the term.- Geomorphology 134, 32-42.

Castiglioni, B. \& U. Sauro, 2002: Paesaggi e geosistemi carsici: proposte metodologiche per una didattica dell'ambiente.- In: Varotto, M. \& M. Zunica, (eds) - Scritti in ricordo di Giovanna Brunetta. Dipartimento di Geografia "G. Morandini", Università di Padova, 51-67.

Corbel, J., 1957: Les Karst du NordOuest de I'Europe e de quelques régions de comparaison; étude sur le róle du climat dans l'érosion calcaire.- Inst. Etud. Rhodaniennes, Univ. Lyon, «Mem. Doc.», 12, Lyon, pp. 531.

Faivre, S. \& Ph. Reiffsteck, 1999: Spatial distribution of dolines as an indicator of recent deformations on the Velebit mountain range.- Geomorphologie: Relief, Processes, Environment, 2, 129-142. 
Faivre, S. \& Ph. Reiffsteck, 2002: From doline distribution to tectonic movements. Example of the Velebit mountain range, Croatia.- Acta Carsologica. 31, 3; 139-154.

Ford, D., 1979: A review of alpine karst in the southern Rocky Mountains of Canada. Bulletin, National Speleological Society of America, 41; 53-65.

Ford, D. \& P.W. Williams, 2007: Karst Hydrogeology and Geomorphology.- Wiley, 562 pp.

Gams, I., 1994: Types of poljes in Slovenia, their inundation and land use.- Acta Carsologica 23: 285-300.

Gams, I., 2000: Doline morphogenetical processes from global and local viewpoints.- Acta Carsologica 29(2): 123-138.

Lehmann, H., 1954: Das Karstphaenomen in verschiedenen Klimazonen.- Erdkunde 8, 112-139.

Mihevc, A., 2001: Speleogeneza divaskega Kraza (The speleogenesis of the Divaca Karst).- Zalozba ZRC, ZRC SAZU, Ljubljana 27: 180.

Mihevc, A., 2007: The age of Karst relief in west Slovenia.- Acta Carsologica 36: 35-44.

Mihevc, A. Slabe, T. \& S. Šebela, 1998: Denuded cavesan inherited element in the karst morphology; the case from Kras.- Acta Carsologica, 27/1, 165-174, Ljubljana.

Nicod, J., 1975: Corrosion de tipe crypto-karstique dans le karst méditerranéen.- Bull. Ass. Geogr. Fr. 428: 284-297.

Phillips, J. D., 2009: Changes, perturbations, and responses in geomorphic systems.- Progress in Physical Geography 33(1), 17-30.

Salomon, J. N., 2000: Précis de Karstologie.- Presses Universitaires de Bordeaux. $251 \mathrm{pp}$.

Sauro, U., 1973: Il Paesaggio degli alti Lessini. Studio geomorfologico (The landscape of the high Monti Lessini plateau: a geomorphological study).- Museo Civ. St. Nat. Verona, m. 6, 161 pp.

Sauro, U., 1991: A polygonal karst in Alte Murge (Puglia, Southern Italy).- Zeitschrift für Geomorphologie, $35,2,207-223$.
Sauro, U., 1995: Highlights on doline evolution.- In: I. Barany-Kevei, Ed. Environmental Effects on Karst Terrains, Universitatis of Szegediensis, Szeged, 34, $107-121$.

Sauro, U., 2002: The Monti Berici: a peculiar type of karst in the Southern Alps.- Acta Carsologica, Ljubljana, 31(3), 99-114.

Sauro, U., 2007: Forms of mixed origin in the karst environment of the Venetian Prealps.- In: A. Tyc \& K. Stefaniak (eds.) Karst and Cryokarst. Univ. of Silesia Faculty of Earth Sciences, Univ. of Wroclaw Zoological Institute, Sosnowiec-Wroclaw, p. 123-128.

Sauro, U., 2009: 07 DJL_Geosystems. In: "Risorse didattiche per la speleologia e il carsismo", Italian Speleological Society (SSI), presentations in four languages (English, French, Italian, Spanish), freely downloadable at "http://document.speleo.it/".

Sauro, U., 2012: Closed Depressions. In: D. Culver \& W. White (eds) Encyclopedia of Caves, Elsevier - Academic Press, Sec. Ed. 2012, 140-155.

Sustersic, F., 1994: Classic dolines of classical sites.- Acta Carsologica 23: 123-156.

Thomas, D.S.G. \& R.J. Allison, 1993: Landscape sensitivity. Chichester: Wiley.

White, W.B., 1988: Geomorphology and Hydrology of Carbonate Terrains.- Oxford University Press, London, 464 pp.

Williams, P.W., 1985: Subcutaneous hydrology and the development of doline and cockpit karst.- Zeitschrift für Geomorphologie, 29: 463-482.

Zambo, L., 1985: The role of clay deposits in the geomorphic evolution of dolines.- In: Pecsi M. (ed.) Environmental and dynamic geomorphology. Akademiai Kiado, Budapest, 97-107.

Zambo, L., 1991: The soil effect in karst development.Proc. Int. Conference on environmental Changes in Karst, Quad. Dipart. Geografia 13, Univ. Padova, 1991, 333-339. 